\title{
STUDI RELEVANSI ALUMNI PG-PAUD UNIVERSITAS NEGERI MALANG DENGAN DUNIA KERJA
}

\author{
Ahmad Samawi \\ Retno Tri Wulandari \\ Eny Nur Aisyah \\ Prodi PG-PAUD FIP Universitas Negeri Malang, Jl. Semarang 5 Malang \\ Email: ahmad_samawi61@yahoo.com
}

\begin{abstract}
Study on Working Relevancy of The PG-PAUD Alumni of State University of Malang.The aim of this research was to describe: (1) the alumni appointment as teacher; (2) the relevant assignment of the alumni; (3) the spread of the alumni, and (4) the guidance to the alumni. This research useda descriptive research design. The results showed that: (a) most of the alumni $(88 \%)$ have been appointed as teacher in private institution and some others $(12 \%)$ in public school, with one month of the long period of waiting for a job;(2) all alumni got the job fitting the competency they have (as childhood teacher); (3) the alumni have been evenly spread to all areas; and (4) most of the alumni (72\%) have been found a good guidance in acoording to their needs from supervisors, principals, the educational department, and the institution they work.
\end{abstract}

Keywords: alumni, PG-PAUD, working relevancy

\begin{abstract}
Abstrak: Studi Relevansi Kerja Alumni PG-PAUD Universitas Negeri Malang. Tujuan penelitian ini adalah mendeskripsikan:(1) pengangkatan alumni sebagai guru; (2) relevansi penugasan alumni; (3) persebaran alumni;dan (4) pembinaan alumni sebagai guru. Penelitian ini menggunakan desain penelitian deskriptif. Hasil penelitian menunjukkan bahwa: (1) sebagian besar alumni $(88 \%)$ telah diangkat sebagai guru PAUD pada yayasan swasta dan sebagian lainnya (12\%) diangkat sebagai guru PNS,dengan masa tunggu 1 bulan; (2) semua alumni bekerja sesuai dengan kompetensinya (sebagai guru PAUD); (3) alumni bekerja tersebar merata; dan (4) sebagian besar (72\%) alumni memperoleh pembinaan dengan baik sesuai kebutuhan dari para pengawas, kepala sekolah, Dinas Pendidikan, dan yayasan tempat bekerja.
\end{abstract}

Kata Kunci: alumni, PG-PAUD, relevansi kerja

Fase usia dini merupakan masa yang sangat peka bagi perkembangan anak. Pada masa itu anak sangat responsive terhadap stimulan dari lingkungannya. Dasar-dasar akan berkembang pertama pada masa itu. Perkembangan fisik motorik, kognitif, sosial emosi, kemandirian, bahasa, seni, nilai dan moral anak sangat ditentukan pada usia dini. Namun, dalam praktiknya kualitas penyelenggaraan dan/ atau layanan Pendidikan Anak Usia Dini (PAUD) masih jauh dari harapan. Penyelenggaraan PAUD dilihat dari budaya dan iklim organisasi belum tertata dengan baik.

PAUD merupakan upaya pembinaan yang ditujukan kepada anak sejak lahir sampai dengan usia enam tahun yang dilakukan melalui pemberian rangsangan pendidikan untuk membantu pertumbuhan dan perkembangan jasmani dan rohani agar anak memiliki kesiapan dalam memasuki dunia pendidikan lebih lanjut. Melalui PAUD, seluruh aspek kemampuan anak dapat dikembangkan 
secara menyeluruh dan holistic sehingga anak dapat mengembangkan seluruh kecerdasan majemuk (Padmonodewo, 2005). Keberhasilan pengembangan seluruh aspek kemampuan itu menjadi landasan keberhasilan pengembangan diri anak di masa akan datang.

UU Nomor 20 Tahun 2003 pada Bab 1, Pasal 1, Butir 14 dinyatakan bahwa PAUD adalah suatu upaya pembinaan yang ditujukan kepada anak sejak lahir sampai dengan usia 6 tahun yang dilakukan melalui pemberian rangsangan pendidikan untuk membantu pertumbuhan dan perkembangan jasmani dan rohani agar anak memiliki kesiapan dalam memasuki pendidikan lebih lanjut. PAUD bertujuan mengembangkan berbagai potensi anak sejak dini sebagai persiapan untuk hidup dan dapat menyesuaikan diri dengan lingkungannya. Bentuk penyelenggaraan PAUD secara formal maupun non formal di dalam masyarakat meliputi: Tempat Penitipan Anak (TPA), Kelompok Bermain (KB), dan Taman Kanak-Kanak (TK/RA).

Sejak tahun 2013 pemerintah telah mengintroduksi kurikulum 2013 dan mengujicobakan di berbagai daerah serta mensosialisasikan kurikulum tersebut di berbagai daerah. Banyak respon diberikan baik dari guru, pakar, pemerhati, orang tua, Lembaga Swadaya Masyarakat (LSM) maupun peserta didik. Uji coba selama dua tahun itu menjadi kandas karena UAN diberlakukan dengan KTSP. Pada jenjang PAUD dan TK ditindaklanjuti dengan penerbitan Peraturan Pemerintah (PP) Nomor 137 Tahun 2014 tentang Standar Nasional PAUD. Implementasi kurikulum dan PP 137 tersebut perlu mendapat dukungan dari tenaga kependidikan, pengawas dan kepala sekolah dalam memberikan pembinaan dan supervisi pembelajaran di kelas.

Kota Malang memiliki tribina cita sehingga menjadi salah satu kota tujuan berbagai masyarakat di tanah air, atau bahkan dari luar negeri. Tribina cita Kota Malang adalah (1) Kota Malang sebagai kota industri; (2) Kota wisata; (3) Kota pendidikan. Sebagai kota pendidikan, Malang memiliki lebih dari 38 perguruan tinggi negeri maupun swasta. Universitas Negeri Malang (UM) sebagai salah satu lembaga pendidikan tinggi negeri yang bereputasi dan berprestasi mendidik mahasiswa menjadi sarjana pendidikan dan non kependidikan. Salah satu program studi kependidikan itu adalah PAUD.
Kedudukan prodi PG-PAUD di UM sangat strategis karena prodi itu menyiapkan calon guru PAUD yang akan mendidik anak, dan hasil didikannya akan menjadi salah satu bagian bonus demografi Indonesia emas tahun 2045, ketika Indonesia berusia 100 tahun merdeka. Hal itu karena, balita yang lahir sekarang ini akan menjadi tenaga kerja produktif pada 32 tahun mendatang. Keberhasilan mereka dalam mengelola negara ditentukan oleh generasi sekarang dalam mendidik dan mempersiapkan mereka di masa depan. Berdasarkan sensus penduduk 2010, kondisi ini memberikan keuntungan demografis karena Indonesia memiliki jumlah penduduk produktif pada saat itu. Seluruh energi seharusnya dikerahkan untuk menyiapkan mereka di masa depan. Para pendidik memperoleh tantangan mendidik anak di dalam konteks kemajuan teknologi. Banyak anak sudah tidak lagi bermain dengan teknologi manual dan sederhana, tetapi dengan teknologi maju. Melalui video games anak sudah bermain dan belajar menghadirkan realitas ke dalam dunia maya imajinatif yang oleh Boudillard (Filsuf Perancis abad ini) disebut dengan Simulacra. Berbagai permainan mereka pelajari dalam video games ini sehingga seakan-akan anak menghadirkan relitas sebenarnya ke dalam dunia semu. Permainan itu menjadi sangat individual, tetapi ada segi positif dan negatifnya. Positifnya, anak sudah belajar secara simulatif berbagai aturan permainan kehidupan nyata jika kelak dewasa. Negatifnya, tidak semua sistem nilai dapat dipenuhi melalui teknologi itu, misalnya perasaan, kepercayaan, keimanan, kasih saying dan sebagainya.

Pada saat itu, dibutuhkan kesiapan Sumber Daya Manusia (SDM) yang memiliki hyper quality yang sanggup menghadapi tantangan zaman; dibutuhkan SDM yang memiliki kemampuan untuk berkompetisi dengan bangsa lain dan sekaligus bekerja sama dalam menghadapi tantangan global. Etos kehidupan bersama selalu dijunjung tinggi dan bila tidak dihormati maka yang bersangkutan akan dikucilkan dan ditinggalkan oleh kemajuan. SDM yang tidak memiliki ethos tersebut seakanakan menjadi komunitas primitive di tengahtengah kehidupan modern. Sehubungan dengan tenaga kerja produktif Indonesia masa depan, dibutuhkan blueprint penyiapan sumber daya manusia berkualitas dengan memberikan nilai 
tambah pada faktor kreatifitasnya. Kreativitas dan inovasi perlu memperoleh tempat yang tinggi dan dihargai sebagaimana mestinya. Pertama, proses pembudayaan baik melalui keluarga, masyarakat, sekolah untuk selalu disiplin SDM. Kedua, proses pendidikan yang menentukan kemampuan berpikir, berkarya, dan bekerja melalui perilaku dan disiplin SDM terampil. Ketiga, wahana jam kerja sebagai tempat melanjutkan proses pembudayaan dan proses pendidikan yang menghasilkan SDM unggul dan kualitas tinggi. Misalnya, sekarang sudah dimulai dengan mengeksplorasi ekonomi kreatif, inovasi di semua bidang perlu dikembangkan. Setiap individu di masa depan perlu memiliki kesiapan keterampilan yang tinggi yang dibutuhkan dunia kerja. Untuk maksud tersebut setiap orang harus mampu berpikir, bekerja, berkarya secara sistematis konsisten, dan terarah dengan biaya minimal menghasilkan produk berkualitas dan diserahkan tepat waktu.

Para ahli dan praktisi pendidikan makin menyadari dan memberikan perhatian yang besar PAUD. Mereka melihat bahwa PAUD memiliki peran yang sangat strategis bagi kelangsungan hidup bangsa dan negara. Kinerja produktif seseorang ternyata ditentukan oleh semua aspek perkembangan anak usia dini. Perkembangan fisik, sosial emosi, bahasa, kognitif, nilai agama dan moral menjadi dasar perkembangan lebih lanjut ketika dewasa. Keberhasilan PAUD akan memberikan kontribusi pembentukan kualitas sumber daya manusia.

Guru memiliki kedudukan strategis di dalam memajukan pendidikan di sekolah. Tidak semua orang dapat melakukannya kecuali guru sehingga pekerjaan guru itu dapat dikatakan pekerjaan professional. Pekerjaan itu memiliki persyaratan meliputi (1) Pendidikan yang cukup panjang, minimal sarjana menurut UU No 14 Tahun 2005 tentang Guru dan Dosen; (2) Jabatan yang melibatkan kegiatan intelektual; (3) Jabatan yang menggeluti suatu batang tubuh ilmu yang khusus; (4) Jabatan yang memerlukan persiapan profesional yang lama (bandingkan dengan pekerjaan yang memerlukan latihan umum belaka); (5) Jabatan yang memerlukan 'latihan dalam jabatan' yang berkesinambungan; (6) Jabatan yang menjanjikan karier hidup dan keanggotaan yang permanen; (7)
Jabatan yang menentukan baku (standar) sendiri; (8) Jabatan yang lebih mementingkan layanan di atas keuntungan pribadi; (9) Jabatan yang mempunyai organisasi profesional yang kuat dan terjalin erat; dan (10) Jabatan guru memiliki kode etik profesi guru.

Seorang guru di dalam melaksanakan tugas profesionalnya perlu memiliki kompetensi tertentu. Pertama, kompetensi pedagogis yaitu suatu kemampuan untuk melakukan pembelajaran yang mendidik sehingga perlu menguasai pemahaman peserta didik, metode mendidik, perkembangan peserta didik dan lainnya. Kedua, kompetensi profesional yaitu kemauan untuk selalu meningkatkan kualitas kemampuan profesionalnya melalui studi lanjut, pelatihan, diklat, workshop, dan belajar mandiri. Ketiga, kompetensi sosial yaitu kemampuan untuk menyesuaikan diri dan berinteraksi dengan lingkungan baik lingkungan kolega, sosial, masyarakat, budaya, dan berinteraksi dengan peserta didiknya. Keempat, kompetensi kepribadian yaitu kualitas diri seperti beriman kepada Tuhan YME, emosi stabil, ramah anak, jujur, bertanggungjawab, sabar, tekun, teliti dan lain sebagainya.

Setelah lulus S1 PG-PAUD, para alumni biasanya segera mencari pekerjaan yang sesuai dengan kompetensinya. Tidak sedikit alumni jurusan lain lama menunggu agar dapat segera bekerja setelah lulus. Bahkan, ada yang terpaksa bekerja diluarkompetensinya karenapersaingannya sangat ketat dan kompetitif. Untuk itu, dibutuhkan kemampuan untuk mampu berkompetisi dengan bangsa lain dan sekaligus bekerja sama dalam menghadapi tantangan global. Etos kehidupan bersama selalu dijunjung tinggi dan bila tidak dihormati maka yang bersangkutan akan dikucilkan dan ditinggalkan oleh kemajuan bersama. Mereka yang tidak memiliki etos tersebut seakan-akan menjadi komunitas primitive yang di tengah-tengah kehidupan modern. Untuk menghadapi tantangan zaman Indonesia berusia satu abad yang akan datang, maka blueprint pembangunan pendidikan yang mampu menyiapkan SDM yang dibutuhkan Indonesia masa depan. SDM yang dimaksud adalah manusia Indonesia yang sehat jasmani dan rohaninya, menguasai hi-tech, memiliki komitmen terhadap bangsa dan negara, mampu bergaul 
dengan bangsa-bangsa di dunia, serta memiliki kepribadian (karakter) yang kuat.

Tatkala melaksanakan tugas profesional, sering kali guru menghadapi hambatan yang tidak dapat diselesaikan sendiri. Mereka perlu mendapat bantuan dan pembinaan dari kaum profesional sejenis di atasnya yaitu supervisor. Tujuan supervisi itu meliputi (1) Untuk meningkatkan kemampuan profesional guru dalam pembelajaran melalui pemberian bantuan secara profesional sehingga proses dan hasil pembelajaran meningkat pula; (2) Memberikan bantuan dalam mengembangkan situasi pembelajaran yang lebih baik secara professional; (3) Menilai kemampuan guru sebagai pendidik dan pengajar guna membantu mereka melakukan perbaikan pembelajaran, sehingga kualitas proses dan hasil pembelajaran juga meningkat.

Menurut Sergiovani (1982), beberapa praktik supervisor di sekolah saat ini dan kebijakan yang muncul dari pemerintah dan dewan sekolah mempengaruhi praktik supervisi, yaitu satu atau kombinasi teori supervisi: manajemen ilmiah tradisional, human relation dan neo-scientific management. Langkah supervisi ilmiah dapat dikemukakan sebagai berikut: (1) Supervisor membuat perjanjian kegiatan supervisor; (2) Memasuki ruang kelas; (3) Guru memberitahu siswa tentang kehadiran supervisor; (4) Guru mempersilakan supervisor ke tempat duduknya; (5) supervisor mengamati tampilan pembelajaran guru;(6)Dengan membericek pada format observasi untuk mencari permasalahan pembelajaran yang dipecahkan bersama guru; dan (6) Meninggalkan ruangan dan pindah ke ruang khusus.

Asumsi psikologi Glickman (2009) meliputi (1) Tidak ada satu pun versi perubahan yang dapat diimplementasikan dalam supervisi; (2) Inovasi bersifat signifikan jika menghasilkan perubahan kearahyanglebih baik;(3)Konflik dan disagreement merupakan modal dan tantangan kesuksesan perubahan; (4) Tekanan kebutuhan masyarakat untuk berubah akan menjadi kalau menjadi kondisi yang mendorong perubahan; (5) Perubahan efektif membutuhkan proses waktu; (6) Membutuhkan perencanaan untuk mengimplementasikan asumsi perubahan; (7) Mengubah budaya institusi tidak dapat mengimplementasikaninvasi tunggal tapi kompleks; (8) Perubahan itu bersifat kompleks;
(9) Tidak ada perubahan rasional yang dapat diterapkan tanpa dukungan semua pihak.

Apakah supervisi memberikan kontribusi dalam pembinaan kemampuan mengajar guru, maka harus dilihat hasil belajar siswanya. Kemampuan guru berkontribusi pada hasil belajar siswa. Jika tidak, mungkin kondisi siswa berat rendah, Apakah ada perbedaan sebelum dan sesudah guru disupervisi, misal kemampuan, keterampilan, kepuasan, dan kedisiplinan kerjanya. Supervisi untuk mengetahui keberhasilan supervisi dan sekaligus pembelajaran serta pembinaan guru.

Kontribusi guru atau pendidik PAUD sangat besar dalam memajukan pendidikan anak. Peran mereka sangat dibutuhkan dalam mengembangkan kemampuan anak secara holistic. Mereka harus memiliki kualifikasi sarjana S1 dan sertifikat pendidik sebagaimana diamanatkan UndangUndang nomor 20 tahun 2003 tentang Sistem Pendidikan Nasional. Penelitian ini bertujuan untuk mendeskripsikan (1) Pengangkatan guru TK/PAUD lulusan PG-PAUD UM di Kota Malang; (2) Relevansi penugasan alumni PGPAUD UM sebagai pendidik atau guru TK/PAUD; (3) Persebaran guru TK/PAUD alumni PG-PAUD UM di berbagai daerah di Kota Malang; dan (4) Pembinaan guru alumni PG-PAUD UM.

\section{METODE}

Penelitian ini menggunakan desain penelitian deskriptif. Penelitian deskriptif ini dimaksudkan sebagai upaya menggambarkan gejala atau fenomena yang berkaitan dengan pengangkatan, penugasan, persebaran dan pembinaan guru PAUD alumni S1 PG-PAUD FIP UM. Populasi penelitian ini ialah keseluruhan alumni S1 PG-PAUD FIP UM yang berada di Kota Malang, yang jumlahnya sebanyak 130 orang. Sampel 20\% diambil secara purposive random sampling, yaitu 26 orang dengan mempertimbangkan sampel yang sesuai dengan tujuan penelitian maka cukup mewakili populasi.

Instrumen pengumpulan data yang dikembangkan dalam penelitian ini adalah angket, pedoman observasi, dokumentasi, dan wawancara mendalam. Angket digunakan untuk mengumpulkan data tentang guru PAUD. Pedoman wawancara digunakan untuk mengumpulkan data tentang pembinaan guru PAUD. Dokumentasi digunakan untuk mengumpulkan data dokumen 
pengangkatan dan penugasan. Pedoman wawancara digunakan untuk mengumpulkan data pembinaan dan kesejahteraan guru PAUD yang tidak dapat dikumpulkan melalui instrumen lainnya.

Teknik analisis data yang digunakan dalam penelitian ini adalah teknik analisis deskriptif kualitatif maupun kuantitatif. Teknik analisis deskriptif kualitatif digunakan untuk menganalisis data pembinaan guru PAUD alumni PG-PAUD UM. Teknik analisis deskriptif digunakan untuk menganalisis data pengangkatan, penugasan, persebaran, dan pembinaan guru PAUD alumni PG-PAUD UM. Sedangkan teknik kuantitatifnya digunakan untuk penghitung persentase dunia kerja alumni PG-PAUD.

\section{HASIL DAN PEMBAHASAN}

\section{Hasil}

\section{Pengangkatan Alumni sebagai Guru}

Setelah lulus, alumni PG-PAUD berusaha segera memperoleh pekerjaan sebagai guru atau bidang lainnya. Berbagai cara dilakukan untuk memperoleh pekerjaan. Sebagian besar $(53,85)$ alumni datang sendiri melamar menjadi guru di sekolah (TK/PAUD), sebagian $(36,46)$ mengikuti tes terbuka melalui seleksi CPNS dan 9,69 diperbantukan di TK tempat mengajarnya (DPK) karena status guru PNS. Berdasarkan tabel 1, diketahui bahwa rekrutmen CPNS untuk guru / TKPAUD masih sangat sedikit. Hal ini dapat juga dilihat dari keberadaan TK Negeri di Kota Malang hanya 5 TK (pembina). Namun demikian, sebagian besar guru TK pembina juga masih tenaga guru tidak tetap (GTT).

Masa tunggu para alumni untuk bekerja setelah lulus relatif tidak lama. Sebagian besar alumin (90\%) memiliki masa tunggu selama sebulan. Sebagian dari alumni yang memiliki masa tunggu sebulan itu ada alumni yang sudah bekerja sebagai guru sebelum lulus. Masa tunggu lebih dari sebulan, menurut alumni karena cari pengalaman di luar mengajar sebagai guru TK/PAUD.

Seluruh alumni PG-PAUD UM bekerja sebagai guru TK/PAUD, dan dari jumlah tersebut yang berstatus sebagai guru PNS hanya $12 \%$ dan sebagian besar lainnya (88\%) bertatus sebagai guru GT dan GTY. Rata-rata penghasilan alumni sebagai guru TK/PAUD masih berada di bawah
UMR Kota Malang (Rp1.175.000,00). Sebagian besar alumni (80\%) bekerja sebagai guru TK/ PAUD berpenghasilan di bawah satu juta rupiah per bulan, dan hanya sebagian kecil saja (20\%) yang berpenghasilan di atas satu juta. Alumni yang berpenghasilan di atas satu juta adalah alumni yang berstatus PNS atau GT/GTY yang sudah tersertifikasi. Bagi guru GT/GTY dan belum tersertifikasi pendidik memiliki penghasilan di bawah satu juta rupiah. Namun demikian, sebagian besar alumni (50\%) memperoleh tunjangan THR, dan sangat sedikit guru TK/PAUD (1,5\%) yang memperoleh tunjangan BPJS, dan 8,5\% mendapat tunjangan asuransi, dan sebagian lainnya mendapat tunjangan profesi $(38,50)$.

\section{Relevansi Penugasan Alumni}

Sebagian besar alumni PG-PAUD UM (80\%) mendapat tugas sebagai guru TK,dan sebagian merangkap sebagai kepala sekolah (10\%) dan merangkap guru SD di sekolah TK-SD satu atap. Seluruh alumni PG-PAUD UM (100\%) memiliki pekerjaan yang relevan dengan kompetensinya sebagai guru. Sebagian besar alumni (90\%) bertugas sebagai guru PAUD di sekolah yang jaraknya antara 1s.d 10 kilometer dari rumahnya. Untuk menuju tempat kerja (sekolah), sebagian besar alumni (80\%) menggunakan alat transportasi pribadi berupa sepeda motor, hanya sebagai kecil saja $(10 \%)$ yang menggunakan angkutan umum seperti angkot,serta ada sebagian (10\%) yang berjalan kaki menuju sekolah karena berdekatan dengan rumah tempat tinggalnya. Penggunaan kendaraan sepeda motor ini menghemat biaya transportasi mengingat penghasilan sebagian besar mereka masih di bawah satu juta, apalagi menggunakan angkot dan mobil tentu akan lebih banyak biaya yang akan dikeluarkan.

\section{Persebaran Wilayah Kerja Alumni}

Tempat kerja alumni PG-PAUD UM sebagai guru PAUD merata di seluruh wilayah kecamatan di kota Malang, yaitu yang bertugas di kecamatan Klojen(30\%), Lowokwaru(15\%), Kedungkandang (20\%), Blimbing (20\%), dan Sukun (5\%). Berkaitan dengan mutasi tempat kerja, diperoleh data bahwa sebagian besar alumni $(80 \%)$ belum pernah mengalami mutasi atau pindah tempat 
kerja dari satu sekolah ke sekolah lainnya. Hanya sebagian kecil saja (10\%) yang pernah mengalami mutasi sekali atau dua kali. Alumni yang pernah mengalami mutasi adalah alumni yang berstatus sebagai guru DPK, dan yang tidak pernah mutasi adalah alumni yang berstatus sebagai GTY.

\section{Pembinaan Alumni sebagai Guru PAUD}

Alumni PG-PAUD UM yang bekerja sebagai guru telah banyak memperoleh pembinaan pengembangan profesi atau pembinaan lainnya. Alumni yang telah memperoleh pembinaan dapat dideskripsikan sebagai berikut. Bahwa sebagian besar alumni (61\%) memperoleh pembinaan dari Dinas Pendidikan, pembinaan dari kepala sekolah $17 \%$, dari pengawas $12 \%$, dan dari yayasan $10 \%$. Frekuensi pembinaan alumni dilakukan secara rutin sebulan sekali sebesar $84 \%$, dan satu semester sekali $16 \%$. Bentuk pembinaan antara lain dilakukan melalui rapat kelas sebesar $61 \%$, kunjungan kelas 23\%, dan lainnya $16 \%$. Materi pembinaan berupa pembinaan pembelajaran sebesar 70\%, pembinaan APE/media pembelajaran $15 \%$, dan pembinaan kepribadian 15\%. Pembinaan dilakukan secara terencana dengan baik sebesar $80 \%$, kurang terencana $20 \%$. Pembinaan dilakukan berdasarkan kesepakatan alumni dan pembina sebesar $90 \%$. Hasil atau nilai pembinaan terhadap alumni selalu disampaikan kepada alumni sebesar $53 \%$, dan sering disampaikan sebesar $42 \%$, dan hanya $5 \%$ yang tidak disampaikan.

Hasil pembinaan disampaikan secara terbuka dan dapat dijadikan sebagai bahan tindak lanjut perbaikan. Proses pembuatan rencana perbaikan tersebut sebagian besar alumni (90\%) merasa dilibatkan, hanya $10 \%$ yang tidak merasa dilibatkan. Mereka yang sudah memperoleh pembinaan dan hasilnya cenderung meningkat, maka akan diberikan apresiasi dalam bentuk kesempatan ikut pelatihan, seminar dan lokakarya ke depan (80\%) dan diberikan masing-masing (10\%) tunjangan penghargaan guru berprestasi dan tunjangan lainnya.

Pada umumnya suasana pembinaan dirasakan dengan penuh keharmonisan dan kekeluargaan (88\%) dan formal (12\%). Artinya, selama ini para alumni memperoleh perlakuan manusiawi dari para pembina dinas pendidikan, yayasan, dan kepala sekolah/pengawas. Hal ini sesuai dengan Glickman (2009) yang menyatakan bahwa pembinaan (supervisi) non directive dilakukan secara humanistik. Perlakukan seperti itu sangat penting.

Pembinaan yang diperoleh para alumni dirasakan sebagai sesuatu yang sangat bermanfaat dalam pengembangan profesinya. (90\%) dan lainnya (10\%) menyatakan bermanfaat. Dampak dari pembinaan itu tampak nyata bagi guru. Mereka meningkat kinerjanya (50\%) dan kinerja siswa (anak) juga meningkat kinerja belajarnya (10\%).

Pembinaan yang diperoleh para alumni PG-PAUD UM dirasakan sudah sesuai dengan kebutuhannya (72\%) dan masing-masing 14\% menyatakan cukup sesuai dan kurang sesuai. Keterlibatan guru TK/PAUD dalam pengambilan keputusan pengembangan sekolah masih kecil. Mereka menyatakan bahwa pengambilan keputusan kebijakan sekolah selalu (50\%) dan sering $(46,2 \%)$ menunggu kepala sekolah dan yayasan. Adanya keterlibatan itu sangat penting dan strategis dalam pengembangan sekolah. Para alumni PGPAUD UM dilibatkan dalam proses pembuatan keputusan, tetapi pengambilan keputusannya masih bergantung pada kepala sekolah dan yayasa. Mereka hanya menerapkan kebijakan sekolah yang sudah ditetapkan kepala sekolah dan yayasan.

Pembinaan sangat diperlukan guru PAUD alumni UM karena dampaknya sangat dirasakan manfaatnya. Hal ini dinyatakan sebagian besar (90\%) guru mersakan manfaatnya dari pembinaan tersebut. Mereka juga menyatakan bahwa dampak dari pembinaan itu pada peningkatan kinerja profesional guru meningkat (55\%) dan kinerja belajar anak (45\%) juga meningkat.

\section{Pembahasan}

Kontribusi guru atau pendidik PAUD sangat besar dalam memajukan pendidikan anak. Peran guru sangat dibutuhkan dalam mengembangkan kemampuan anak secara holistic. Guru harus memiliki kualifikasi sarjana S1 dan sertifikat pendidik sebagaimana diamanatkan UndangUndang nomor 20 tahun 2003 tentang Sistem Pendidikan Nasional.

Setelah lulus, alumni Prodi S-1 PG-PAUD pada umunya bekerja sesuai dengan latar belakang pendidikan dan kompetensi yang dimiliki, yaitu sebagai guru atau pendidik pada pendidikan anak 
usia dini (PAUD). Hal ini sejalan dengan PP Nomor 19 Tahun 2005 pasal 1 yang menyatakan bahwa guru adalah pendidik profesional dengan tugas utama mendidik, mengajar, mengarahkan, melatih, menilai dan mengevaluasi pada pendidikan. Berdasarkan PP tersebut juga disebutkan tentang standar pendidik bahwa pendidik harus memiliki kualifikasi akademik dan kompetensi sebagai agen pembelajaran, sehat jasmani dan rohani, serta memiliki kemampuan untuk mewujudkan tujuan pendidikan nasional, yang meliputi (a) kualifikasi akademik minimal S-1, (b) latar belakang pendidikan sesuai dengan bidang yang diajarkan.

Guru berkualitas selalu menjadi tuntutan di berbagai jenjang dan jenis institusi pendidikan (Hendri, 2010). Hasil penelitian Mariyana (2005) mendapati bahwa penyelenggara program pendidikan guru anak usia dini untuk lebih memperhatikan kualitas kompetensi dan kualifikasi lulusan. Hal senada juga dikemukakan Syahrul (2009) mendapati bahwa profesionalitas guru harus menjadi perhatian serius program studi, mengingat, guru memiliki tugas dan peran bukan saja memberikan informasi pengetahuan tetapi juga membentuk sikap dan jiwa anak didik.

Relevansi kerja alumni PG-PAUD UM yang pada umumnya sebagai pendidik PAUD selaras dengan tuntutan terhadap profesionalisme guru PAUD. Profesionalisme guru dituntut agar terus berkembang sesuai dengan perkembangan ilmu pengetahuan, teknologi dan kebutuhan masyarakat, termasuk kebutuhan terhadap sumber daya manusia yang berkualitas dan memiliki kapabilitas untuk mampu bersaing di era global. Guru merupakan pekerjaan yang terkait langsung dengan kebutuhan masyarakat. Guru merupakan "the front linear" dalam upaya peningkatan mutu pendidikan nasional (Sa'ud, 2000), dan merupakan salah satu penentu keberhasilan dalam upaya peningkatan mutu dan inovasi pendidkan (Fullan, 1992). Guru memegang peranan strategis terutama dalam upaya membentuk watak bangsa melalui pengembangan kepribadian dan nilai-nilai yang diinginkan (Gaffar, 1998). Oleh karena itu, peran guru sulit digantikan oleh yang lain. Atas dasar ini maka tuntutan profesionalitas guru yang antara lain ditunjukkan oleh kompetensi yang dimiliki guru mutlak diperlukan.
Alumni PG-PAUD UM telah tersebar relatif merata di berbagai kecamatan di seluruh kota Malang. Para alumni PGPAD UM yang bekerja sebagai guru telah banyak memperoleh pembinaan pengembangan profesi. Artinya, selama ini alumni PG-PAUD memperoleh pembinaan dari berbagai pihak, baik dari pembina dinas pendidikan, yayasan, dan kepala sekolah. Pembinaan itu sangat diperlukan oleh setiap pendidik/guru, termasuk guru PAUD. Pembinaan, atau biasa disebut sebagai supervisi, merupakan sebuah usaha yang sistematis dan berlangsung secara terus menerus dalam upaya mendorong dan mengarahkan guru agar berkembang secara lebih efektif dalam usaha mencapai tujuan pendidikan (Abu Bakar, 2011). Pembinaan merupakan pelayanan yang diberikan oleh supervisor untuk membantu guru agar menjadi guru yang cakap dan sesuai dengan perkembangan ilmu pengetahuan dan khususnya perkembangan dalam ilmu pendidikan sehingga guru dapat menjalankan tugas profesinya dengan lebih baik dan lebih kreatif. Hal ini sejalan dengan penjelasan Sutiasna (1987) bahwa pembinaan merupakan suatu bentuk pelayanan, bimbingan bagi guru melalui peningkatan kemampuannya agar mutu pendidikan dan pengajaran yang dilakukan semakin meningkat.

Pembinaan yang diberikan oleh berbagai pihak (Kepala Dinas, Kepala Sekolah, Pengawas, dan lainnya) kepada alumni sebagai guru PAUD merupakan bentuk komitmen bersama antara pembina dan yang dibina (yaitu guru) terhadap peningkatan kualitas pendidikan, komitmen bersama terhadap lembaga pendidikan. Hal demikian sejalan dengan temuan penelitian Siburian (2014) yang mendapati bahwa kesediaan kepala sekolah dan juga guru dalam upaya peningkatan kemampuan profesionalnya merupakan bentuk komitmen terhadap lembaga tempat bertugas. Komitmen Kepala Sekolah antara lain ditunjukkan oleh kesediaannya memerankan perannya sebagai pembina kepada guru-guru yang mengajar di lembaga tersebut sehingga kualitas layanan pendidikan di lembaga itu menjadi lebih baik. Kesediaan guru menerima arahan, bimbingan dan masukan dari para pembina, merupakan bentuk komitmen guru terhadap kompetensi profesionalnya sebagai pendidik, dan dengan 
cara demikian, guru dapat memperbaiki dan/atau meningkatkan kemampuan dalam melaksanakan tugas pembelajaran kepada anak didiknya.

\section{KESIMPULAN DAN SARAN}

\section{Kesimpulan}

Berdasarkan hasil analisis data diambil beberapa kesimpulan bahwa pada umumnya alumni PG-PAUD UM telah bekerja pada bidang sesuai dengan kompetensi yang dimiliki, yaitu sebagai pendidik PAUD. Bahwa alumni PGPAUD UM pada umumnya telah diangkat menjadi guru PAUD sekitar 1 bulan setelah lulus. Alumni pada umumnya ditugaskan sebagai guru PAUD, dan memperoleh gaji masih di bawah UMR Kota Malang. Tempat kerja alumni pada umumnya tidak jauh dari tempat tinggalnya, dan tersebar di seluruh wilayah kecamatan di Kota Malang. Ketika menjalankan tugasnya sebagai guru PAUD, alumni telah memperoleh pembinaan dengan baik dari kepala sekolah, pengawas, dinas pendidikan dan juga pengurus Yayasan tempat alumni bekerja.

\section{Saran}

Untuk meningkatkan relevansi kerja alumni, program studi PG-PAUD diharapkan dapat meningkatkan kualitas ikatan dengan alumninya. Selain menambah intensitas komunikasi antar alumni, program studi PG-PAUD memperkuat forum komunikasi antar alumni sebagai media bagi, oleh dan untuk seluruh alumni dan mudah diakses, baik secara online maupun offline.

\section{DAFTAR RUJUKAN}

Bakar, A. 2011. Supervisi Pendidikan Agama Islam. Jurnal Sosial Budaya. 8 (1), JanuariJuni 2011.

Fullan, M. 1992. The New Meaning of educational Change. Toronto: OISE Press Publishing Co.

Gaffar, F. G. 1998. Menghargai Pengabdian Para Guru. Jurnal Pendidikan. 3 (XVIII)

Glickman, C.D. et al. 2009. The Basic Guide to Supervision and Instructional Leadership. Boston: Allyn and Bacon, Inc.

Hendri, E. 2010. Guru Berkualitas: Profesional dan Cerdas Emosi. Jurnal Sang Guru. 1 (2).

Mariyana, R. 2005. Kompetensi Guru dalam Pembelajaran Berbasis Bimbingan di Taman Kanak-kanak

Padmonodewo, S. 2003. Pendidikan Anak Prasekolah. Jakarta: PT Rineka Cipta.

Sa'ud, Udin S. 2000. Standarisasi Lulusan dan Program Pendidikan Prajabatan Guru Profesional Sebuah Harapan. Dalam Mimbar Pendidikan, Jurnal Pendidikan (3, XIX).

Sergiovani, T.J. 1982. Supervision of Teaching. ASCD.

Siburian, P. 2014. Determinant Factors of Organizational Commitment of Elementary School Teachers in North Sumatra Indonesia. International Journal of Sciences: Basic and Applied Research (IJSBAR). 18 (1): 208-220.

Syahrul. 2009. Pengembangan Profesi dan Kompetensi Guru Berbasis Moral dan Kultur. Jurnal MEDTEK, 1 (1). 